\title{
PREREQUISITES AND APPROACHES TO FORCE MODERNIZATION IN A TRANSITION PERIOD
}

\author{
Todor TAGAREV
}

$\mathrm{T}$ The new security challenges in the beginning of the new century and the pace of technological innovation force politicians and planners around the world to search for ways to modernize military forces while providing for a broader spectrum of missions and tasks. For a country in transition, this search is complicated by severe resource constraints, lack of experience in market environment and relevant organizational culture. Of particular importance is the dynamics of civil-military relations that may hinder appropriate reform efforts. ${ }^{1}$

This article covers key issues of defense modernization and re-equipment of armed forces, including resource aspects of modernization. It is based almost entirely on the Bulgarian experience in the last three years. Bulgaria is a country in transition that differs from other countries willing to join NATO and the European Union by its excessive military and defense industrial infrastructure, inherited from the recent past. Nevertheless, the focus is on common principles; the analysis of their implementation is supported with specific examples from the experience of the Bulgarian Ministry of Defense. First, defense reform requirements are described and the necessity to introduce a rigorous defense resource management system is rationalized. Secondly, we describe organizational and procedural changes, essential for the creation of a flexible acquisition process, compatible with acquisition systems and practices of NATO and EU member countries. Next, we outline the main elements of the new acquisition planning, listing current priorities and presenting an ongoing force modernization study. The article covers also the role of research and development in modernization, as well as potential national and international cooperation activities.

\section{Force modernization in the framework of defense reform}

The task to modernize security and defense is particularly challenging for countries transitioning from authoritarian regimes to democracy and from command to a market 
economy. Bulgaria is one such country, which is also a fervent candidate for membership in NATO and the European Union.

Given conceptual, economic, and social problems of defense reform, Bulgaria made significant progress in the last three years. Milestone developments were the adoption of a new Concept for National Security, ${ }^{2}$ new Military Doctrine ${ }^{3}$ and reform plans known as "Plan-2004". The reform plans were developed under strict civilian oversight to allow balanced and gradual growth of capabilities to perform expected tasks and missions. Figure 1 represents the general defense planning framework ${ }^{4}$ implemented in the Bulgarian Ministry of Defense. Thus, modernization plans are developed in a coherent way to meet national security requirements. Particularly, force development plans are designed so that the Bulgarian military would effectively perform 18 tasks grouped in six mission areas. Missions and tasks are listed in Annex A. ${ }^{5}$ Plans and programs to modernize weapon systems, equipment, command and control, communications and information systems, intelligence, surveillance and reconnaissance systems (C4ISR), defense and dual-use infrastructure and building host nation support (HNS) capabilities are integral part of the defense planning process. The implementation of this general planning framework is essential in providing guidance, e.g., to build and sustain required defense capabilities accounting for resource constraints and in coordination of modernization plans with other force development activities.

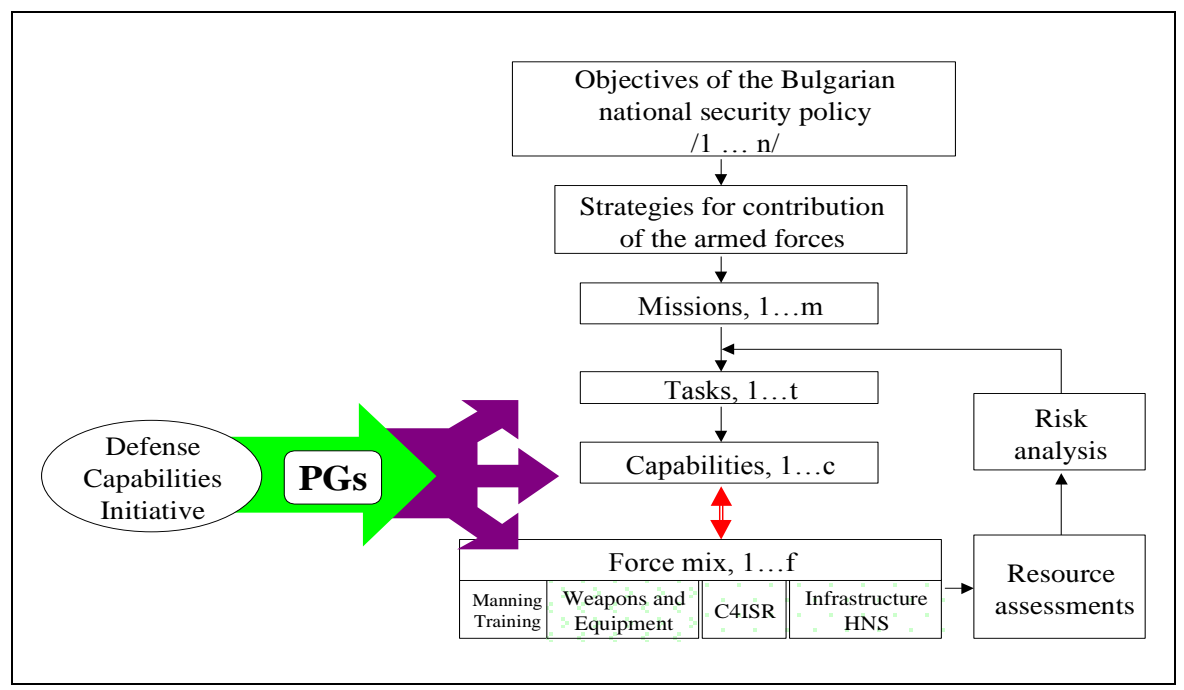

Figure 1: Modernization decisions in the defense planning framework. 
Furthermore, Bulgaria introduced a rigorous defense resource management system, fully compatible with the NATO defense planning system. Finally, as one of the states striving for NATO membership in the near future, Bulgaria has its own Membership Action Plan, annual programs for its implementation and participates in the NATO Planning and Review Process (PARP). In regard to modernization, and force development as a whole, plans are designed to meet the requirements of the NATO Defense Capabilities Initiative (DCI) that during the planning process is specified in a set of Partnership Goals (PGs). Although current plans do not specifically focus on capabilities required by EU member states, their implementation would allow significant future contribution to overcome the capability gaps defined by the European Union.

Given these tools, the will of all political parties represented in Parliament and the dedication of the political majority and its Government, Bulgarian planners were able to draft mid- and long-term plans, that approximate future costs and budget levels with a reasonable accuracy. These plans are based on the assumption of sustaining the defense budget as a percentage of the GDP and are refined to better meet requirements of future NATO membership. Table 1 presents forecasted defense budget levels and forecasted budget distributions. ${ }^{6}$

Table 1

MOD BUDGET FOR THE PERIOD 2001-2015 BY APPROPRIATIONS /Million BGN/

$\begin{array}{lrrrrrrrrr} & 2001 & 2002 & 2003 & 2004 & 2005 & 2006 & 2007 & 2010 & 2015 \\ \begin{array}{l}\text { Personnel } \\ \text { cost }\end{array} & 445.0 & 489.3 & 482.1 & 419.2 & 459.1 & 503.0 & 551.3 & 713.7 & 872.2 \\ \text { O\&M } & 216.3 & 190.3 & 210.7 & 296.6 & 286.2 & 288.6 & 284.5 & 289.3 & 290.9 \\ \text { Investment } & 84.3 & 151.7 & 208.6 & 255.4 & 300.9 & 337.7 & 368.9 & 438.7 & 508.1 \\ \text { R\&D } & 2.5 & 4.6 & 6.9 & 9.6 & 13.2 & 14.7 & 15.3 & 19.1 & 22.3 \\ \begin{array}{l}\text { Budget } \\ \text { MoD }\end{array} & \mathbf{7 4 8 . 1} & \mathbf{8 3 5 . 9} & \mathbf{9 0 8 . 3} & \mathbf{9 8 0 . 8} & \mathbf{1 0 5 9 . 4} & \mathbf{1 1 4 4 . 0} & \mathbf{1 2 2 0 . 0} & \mathbf{1 4 6 0 . 8} & \mathbf{1 6 9 3 . 5} \\ & & & & & & & & & \end{array}$

MOD BUDGET FOR THE PERIOD 2001-2015 BY APPROPRIATIONS /in percentage/

$\begin{array}{lrrrrrrrrr} & 2001 & 2002 & 2003 & 2004 & 2005 & 2006 & 2007 & 2010 & 2015 \\ \text { Personnel } & 59.5 \% & 58.5 \% & 53.1 \% & 42.8 \% & 43.3 \% & 44.0 \% & 45.2 \% & 48.9 \% & 51.5 \% \\ \text { cost } & & & & & & & & & \\ \text { O\&M } & 28.9 \% & 22.8 \% & 23.2 \% & 30.2 \% & 27.1 \% & 25.2 \% & 23.7 \% & 19.8 \% & 17.2 \% \\ \text { Investment } & 11.3 \% & 18.1 \% & 23.0 \% & 26.0 \% & 28.4 \% & 29.5 \% & 29.9 \% & 30.0 \% & 30.0 \% \\ \text { R\&D } & 0.3 \% & 0.6 \% & 0.8 \% & 1.0 \% & 1.2 \% & 1.3 \% & 1.3 \% & 1.3 \% & 1.3 \%\end{array}$


This budget distribution provides for the necessary maintenance of the planned force structure, training according to NATO standards and modernizing the force to build and sustain the capabilities necessary for national defense, reasonable contribution to NATO or EU crisis response operations and significant contribution to collective defense. Strictly following reform plans, after 2004 the modernization budget ${ }^{7}$ will amount to 25 percent of the Bulgarian defense budget. Thus, Bulgaria will meet the Common European Security and Defense Policy target figure ${ }^{8}$ and will exceed the NATO floor for modernization spending. ${ }^{9}$ Figure 2 shows one modernization indicator, defined as defense spending in purchasing power parity dollars per troop.

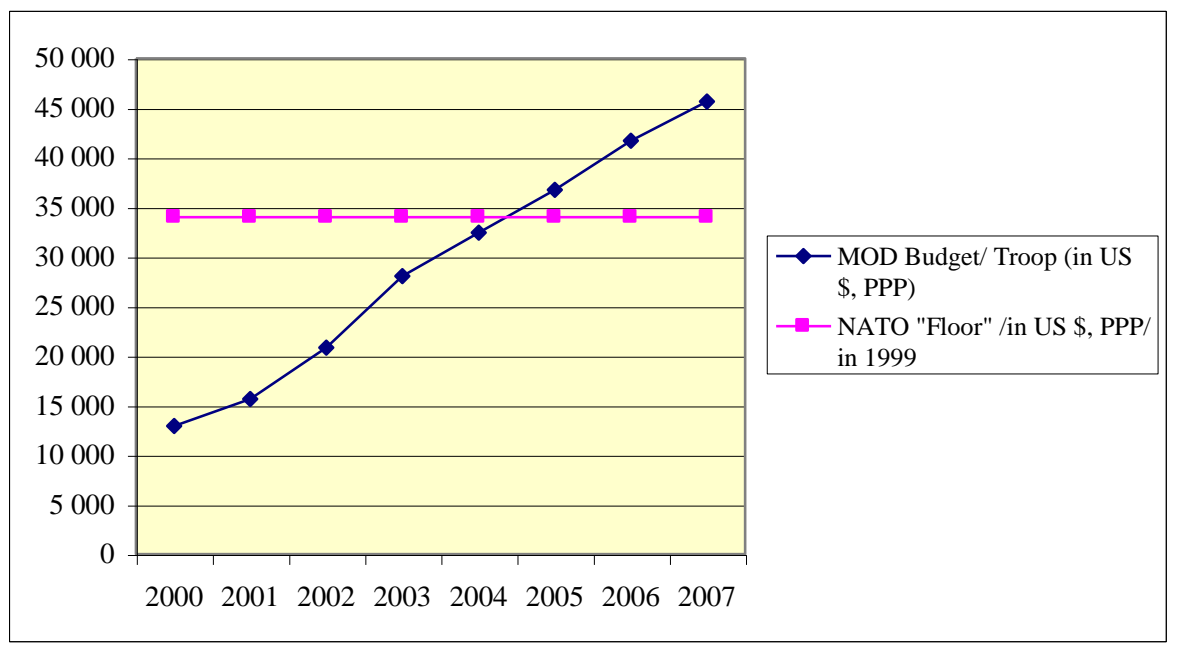

Figure 2: Modernization opportunities for the Bulgarian armed forces compared with the 1999 NATO floor. ${ }^{10}$ The indicator is defined as purchasing power parity (PPP) dollars per troop. Calculations are based on planning figures for personnel and budget distribution. ${ }^{11}$

Furthermore, additional money for modernization would be available through security assistance programs and specific national programs, i.e., for harmonization of the frequency spectrum management with EU norms. These resources may amount to over 10 percent of the modernization budget. They are not included in table 1 .

Thus, the comprehensive approach to defense reform and the strict implementation of reform plans provide opportunities for modernization. To use these opportunities wisely, a number of prerequisites have to be met. The experience of Bulgaria provides examples of organizational and procedural changes, considered essential for adequate modernization. 


\section{Organizational and procedural prerequisites}

Analyzing problems of the existing acquisition system, the Bulgarian Ministry of Defense launched an effort to adapt the acquisition process to provide for more effective spending of taxpayers' money. Functioning closely with the resource management system, the new acquisition system (draft version from August 2001) is intended:

- To relate mission needs (capability gaps) to user/operational requirements to system and technical requirements to procurement decisions;

- To account for the life cycle cost of intended materiel solutions;

- To be transparent to decision makers, potential users and suppliers;

- To provide flexibility and efficiency;

- To be compatible with the acquisition systems of NATO and member countries. $^{12}$

In order to support this advanced acquisition system, the Council of Ministers by its Decree \# 58 of 08 March 2001 established the Armaments Policy Directorate (APD) as the principal coordinator of all modernization activities. According to the current Organic Law of the Ministry of Defense, APD performs the following main functions:

- Coordinates planning, programming and the implementation of the armaments policy;

- Develops the scientific and technological policy of the Ministry of Defense and organizes its implementation;

- Supports the implementation of the standardization, codification and state quality control of armaments and special products, their certification, as well as the certification of quality assurance systems of the producers;

- Supports the development of policy for scientific, R\&D and armaments cooperation.

Furthermore, the Director of the Armaments Policy Directorate is national representative to the Conference of National Armaments Directors (CNAD) with the responsibility to coordinate planning, programming and implementation of the armaments policy.

As National Armaments Director, the Director of APD coordinates the national representation in all CNAD Work Groups - NATO Army, Navy and Air Force armaments groups, the Research and Technology Organization, NATO Industrial Advisory Group, as well as the groups on acquisition practices, standardization, quality assurance, codification, etc. Thus, Bulgaria profits from the transfer of 
comprehensive knowledge in formulation of policies, management practices, qualification standards, technical requirements, etc.

Within the Ministry of Defense, in cooperation with the J4, J5 and J6 directorates of the General Staff, the Procurement Directorate, the Budget Planning and Management Directorate, the Executive Agency for Tests and Evaluations, and the Institute Advanced Defense Research, the APD organizes the execution of the activities at all stages of the systems life-cycle, from concept to disposal. The interaction with the Planning, Programming and Budgeting System is realized through the MoD Defense Planning Directorate (DPD) and the Defense and Force Planning Directorate (J5) of the General Staff, while the logistic support is executed through the Joint Materiel Command.

Comparing this organizational structure with the experience of NATO countries, the Armaments Policy Directorate, parts of the Procurement Directorate and the Executive Agency for Armaments and Equipment Testing and Control Measurements can be seen as a "Procurement Agency" - partner with CNAD and its working groups. Additionally, the Logistics Directorate (J4) of the General Staff and the Joint Logistics Command are roughly equivalent to a "Logistics Organization" - the partner of the NATO Materiel and Supply Agency (NAMSA).

Furthermore, a Modernization Council has been established for formulating policy in the field of armaments, equipment and infrastructure. This Council is similar in functions to the US Defense Acquisition Board. In interaction with the Programming Council and the Defense Capabilities Council (to be established), the Modernization Council gives the main directions for development of the armament and equipment for the needs of the armed forces. In this interaction, the Programming Council identifies defense policy priorities, and the Defense Capabilities Council identifies mission needs, authorizes operational requirements, provides guidance and priorities balancing planned defense capabilities.

The activity of the three Councils is supported by Expert Technical-Economic Councils on C4I Systems, on Military Standardization and on Research and Development (R\&D), as well as Expert Technical Committees (ETC) on the Services level. The interaction of all these organizations is represented on figure 3. 


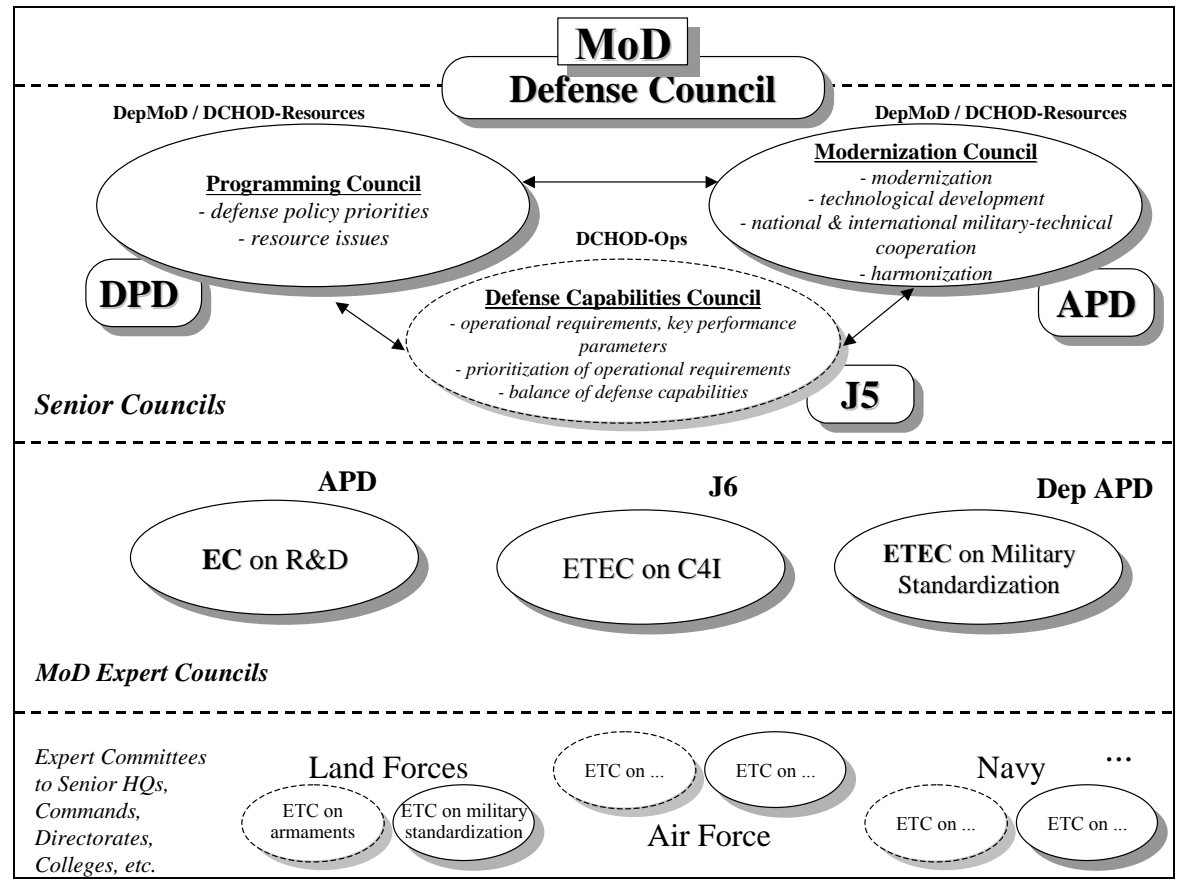

Dashed lines represent organizations in forming. The following abbreviations are used: DPD- Defense Planning Directorate; APD - Armaments Policy Directorate; J5 - Defense and Force Planning Directorate at the General Staff; J6 - Communications and Information Systems Directorate at the General Staff; DCHOD - Deputy-Chief of Defense; EC - Expert Council; ETEC- Expert Technical-Economic Council; ETC - Expert Technical Committee.

Figure 3: Organizational support for the acquisition process.

The implementation of policy priorities under resource constraints is further facilitated by the integration of the force development and modernization in the comprehensive structure of defense programs. Currently, the programs for modernization are inherent part of the programming process in the Ministry of Defense and fall under the following program structure:

\section{Program number:}

\# 1.6: Weapons systems and equipment for the Land Forces

\# 2.6: Weapons systems and equipment for the Air Force

\# 3.6: Weapons systems and equipment for the Navy

\# 4.8: Systems and equipment for logistics and medical support

\# 12: C4, Intelligence, Reconnaissance and Surveillance systems (C4ISR) 
Program \# 12 covers the introduction of advanced information technologies in education, staff training, simulation based training of troops, as well as navigation systems and systems for electronic surveillance and warfare. The development of defense and dual-use infrastructure is considered as part of the respective modernization programs of the services and the joint logistics command. Additionally, scientific and R\&D support for modernization is provided through a centrally managed program, established as main program \# 10.

All future modernization programs are developed by the respective services and commands under the coordination of the Armaments Policy Directorate of the Ministry of Defense. The authorized modernization programs are part of the Program Decision Memorandum (PDM) of the Ministry of Defense. PDM has a six-year horizon and serves for budgeting for the first of the future years.

Modernization project management is carried out by Integrated Project Teams. In practice, this approach has been realized in the implementation of the Field Integrated Communication and Information System (FICIS) for the needs of the Bulgarian Armed Forces units and formations, the Air Sovereignty Operational Center (ASOC), etc. ${ }^{13}$ The main directives for their development and the solution of problems of critical importance is done by Supervisory Boards. There is only one level of subordination between the project team and the body controlling the acquisition processes and the modernization programs - the Modernization Council.

The document information base through which the defense acquisition activities are carried out incorporates a number of additional normative and standardization documents regulating the requirements to the individual stages. Notable among them are the Law on Public Tenders, ${ }^{14}$ the Regulations for Public Tenders, and the Instruction on Planning, Organization and Control of Logistic Support, Construction and Construction Services in the Ministry of Defense. ${ }^{15}$ The main purpose of these documents is to provide transparency of planning and competitiveness in the implementation of procurement decision.

\section{Rigorous planning for modernization}

Since the start of the defense reform, capital investments continuously grow. Figure 4 represents the trend of increase $(1 \mathrm{BG} \mathrm{Lev}=1 \mathrm{DM})$, where security assistance programs are focused on the introduction of advanced communications and information systems. For the current year, the spending on $R \& D$, overhaul, modernization and procurement of weapon systems and equipment, and construction accounts for 11 percent of the defense budget, while planned security assistance is equivalent to another 3.5 percent of the defense budget. One additional program dedicated to harmonization of the frequency spectrum with EU norms brings 
investments in communications systems equivalent to another 5.8 percent of the defense budget. Thus, Bulgaria already has conditions for implementation of moderate modernization programs.

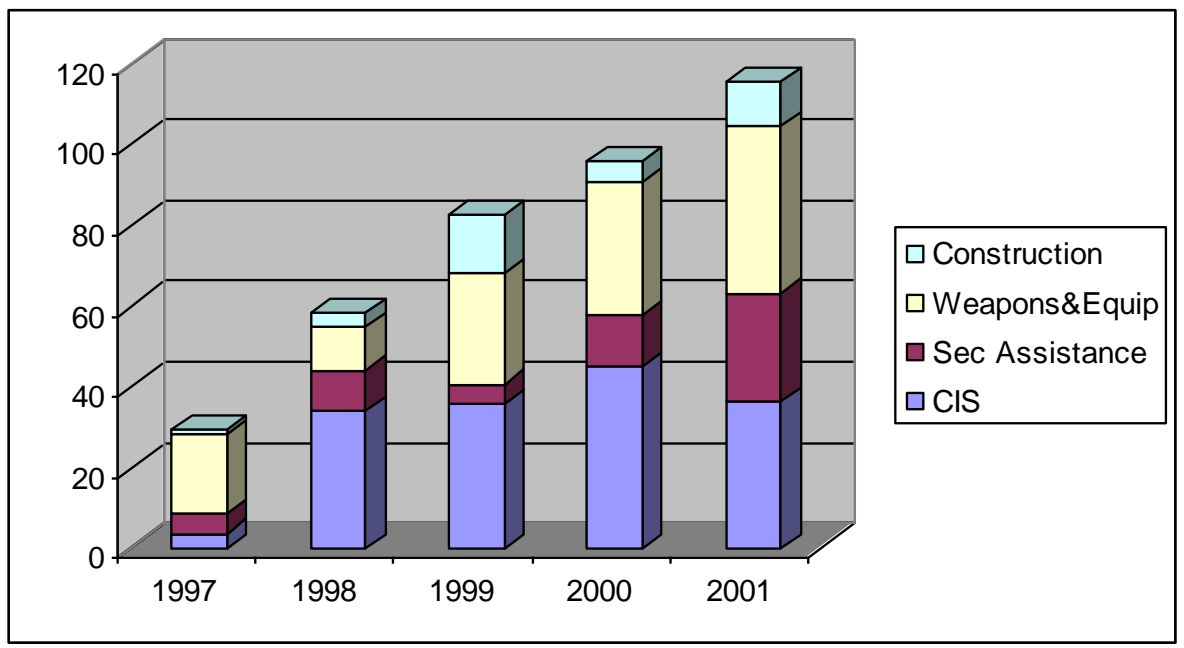

Figure 4: Capital investments, mln. BG levs

Through the Military Doctrine, in 1999 the Bulgarian Parliament defined the initial modernization priorities. According to its article 97 “... priority in the modernization of the Armed Forces is that they have the control, command, surveillance, intelligence, communications, mutual identification, computerization, navigation, (including with airspace systems, means and technologies), that would enable interoperability with the Armed Forces of the NATO countries and take into account the country's transformation to an information society."

Then, with the introduction of the planning framework and the defense resource management system described in the previous section, the following priorities for modernization were defined for the years till 2006.

General modernization priorities:

- Improvement of the $\mathrm{C} 2$ at international, national, strategic and tactical levels;

- Development of infrastructure for logistics support;

- Improvement of intelligence, surveillance and night vision systems;

- Developments of plans to introduce high precision weapons; 
- Establishment of simulation training centers for HQs and troops, as well as simulation-based training of soldiers and crews;

- Improvement of capabilities to transport troops, equipment and supplies;

- Introduction of distance learning systems;

Priorities in modernizing Land Forces:

- Clothing, equipment and medical support for troops and HQs participating in Partnership for Peace (PfP) operations;

- Autonomous ground sensors for detection, identification and surveillance of combat equipment and people;

- Surveillance and targeting systems for artillery units;

- Modernization of short and very-short range air defense capabilities;

- Facilitate computer-assisted exercises at operational and tactical levels for all HQs and units participating in PfP operations;

Priorities in modernizing the Air Force:

- Modernization of aircraft and equipment dedicated for participation in NATO-led operations;

- Ensure full NATO interoperability of communications, navigation and supporting equipment of two military airbases;

- Start introduction of advanced ground-to-air and air-to-air missiles;

- Plan for introduction of advanced multipurpose fighter;

- Complete the build-up of an interoperable IFF system;

- Integrate the national Air Sovereignty Operations Center (ASOC) with the NATO air defense system;

Priorities in modernizing the Navy:

- Modernize the C2 system of the Navy and introduce Link-11 for frigates;

- Equip the units dedicated for peace support operations with interoperable $\mathrm{FM}$ and SW communications, including security equipment;

- Introduce capabilities for mine clearing at depths up to 80 meters;

- Modernize auxiliary ships;

- Introduce ship and port NATO standard equipment for fuel and water supplies;

Priorities in modernizing logistics:

- Provide NATO-interoperable C2 system for operational logistics and support; 
- $\quad$ Equip airports, ports and railway stations for Host Nation Support (HNS) according to NATO standards;

- Provide capabilities for automatic logistics information processing and distribution among national units and regional HQs according to NATO standards;

- Establish organization and provide technical equipment for introducing F-34 fuel;

- $\quad$ Provide equipment for a field hospital with 80 beds and surgical capacity;

Priorities in modernizing C4ISR systems:

- Continue the priority development and implementation of C4ISR systems to achieve interoperability with NATO at strategic, operational and tactical levels;

- Build a National Military Command Center;

- Operational readiness of a field integrated communications and information system for one mechanized brigade and other units dedicated for NATO-led operations;

- Equip all units and HQs dedicated for peace support operations with commercial mobile SATCOM terminals.

For implementation of these priorities, as well as to support the development of a long-term modernization plan till 2015, the Bulgarian Ministry of Defense is currently conducting a comprehensive Force Modernization Study. This long-term plan is considered of particular importance because the next round of NATO enlargement would require the aspirants to demonstrate that they can make significant contribution to NATO's overall military effectiveness - that they will be contributors and not just consumers of security. The expectation is that the Alliance will be focusing on the capabilities and ability of candidates to contribute to NATO's old and new missions. Since Bulgaria expects invitation for membership during the NATO Summit in 2002, there is a need to begin developing a coherent, long-term plan for modernization and rearmament, including host nation support capabilities of the Bulgarian Forces well in advance of the Summit. In this regard the MoD with the assistance of the US Government performs this study as basis for the development of a long-term modernization plan for the Bulgarian Armed Forces to meet future security challenges and prepare for NATO membership.

This study builds on the final report of the "Bulgarian defense reform study,"16 "Plan for organization and development of the MoD by the year 2004," Action Plan including the Partnership Goals, and the C4I study. ${ }^{18}$ It will help the 
Bulgarian MoD to establish its planning priorities for defense equipment modernization and rearmament in three phases: by 2002, by 2004, and by 2015 .

The study has to fulfill the following tasks:

\section{Task 1. Equipment Modernization and Rearmament:}

Building on the existing assessments of the security environment and its implications on the defense strategy and the military missions a joint Bulgarian-US team will evaluate Bulgarian force plans and structure to assess its capability to execute the military missions and tasks, with minimum risk and within forecasted resources. In this task, the Joint Team will target near-term imperatives for ensuring the national security of Bulgaria. The Joint Team will develop capabilities typical of modern Western militaries. This will include how the Bulgarian military can position itself to take advantage of the rapid advances of the military technologies. The study will also analyze the current status of the Bulgarian armed forces armament and identify, in light of the new missions, weapon systems that can be modernized and weapon systems that have to be declared obsolete, as well as ways to deal with the obsolete equipment. The findings of the study should give sufficient basis for the development of a detailed program for modernizing armaments and infrastructure.

\section{Task 2. Impact and Implications of Defense Capabilities Initiative:}

The Joint Team will examine the possible impact and implications of DCI on Bulgaria's military strategy and modernization plans. The Team will also develop an implementation strategy, outlining the key tasks that need to be carried out by Bulgaria to meet the DCI requirements. The team will identify those niche areas in which investment can bring greatest DCI returns.

\section{Task 3. Defense Industry Development:}

The Joint Team will analyze the potential of the Bulgarian defense industry in the light of its ability to support the modernization effort of the Bulgarian Armed Forces and identify possible areas of cooperation between Bulgarian and US defense industries, as well as trends for future military technology developments.

Additional to the support by the US Government, the Bulgarian Ministry of Defense is in contact with relative NATO authorities, as well as with other strategic partners to examine specific areas of modernization. The final responsibility, however, rests with the Bulgarian Government. Furthermore, the current intention is to send the Modernization Plan 2015 to Parliament that would provide guidance, exercise final authority and dedicate resources in long term. 
The Modernization Plan 2015 will address several groups of issues, among them:

- Platforms. We expect decisions on a smaller numbers of multipurpose platforms of fewer types accounting for logistical and interoperability requirements;

- C4ISR. The expected focus is on integration of commercial-of-the-shelf (COTS) state-of-the-art products and dual-use technologies in joint technical architecture following the requirements of the NATO common operating environment; ${ }^{19}$

- Infrastructure. While releasing a big part of its excessive defense infrastructure, Bulgaria will plan upgrades and modernization of the remaining military and dual-use infrastructure to provide interoperability and host nation support capabilities.

- $\quad$ Assets from trade. For certain capabilities the Bulgarian armed forces would need to use assets from trade, e.g., for mobility (land, air and sea transport).

From the force modernization study and the debate on modernization we would expect a stronger parliamentarian oversight and long-term support by the People's Assembly (The Bulgarian Parliament) to provide stability and continuity of defense plans and programs, and in particular, of defense modernization programs.

\section{Organization of defense $R \& D$}

Closely following the major decisions on defense reform, in the spring of 1999 the Minister of Defense commissioned a study on the status of Bulgarian defense R\&D. From April till June 1999, the assigned working group analyzed all aspects of defense $R \& D$ and proposed a Concept for consolidation of the R\&D institutes. It concluded that the existing system for defense R\&D is cumbersome and inefficient and does not provide the necessary support to defense reform. For any practical purposes, in the early 1990s defense $R \& D$ organizations had not been subject to reform or accommodation to changing security requirements and declining defense budgets. At the time of the study, twelve R\&DTE organizations in the Ministry of Defense employed over 1,000 people. Over 700 scientists and engineers were employed in four main institutes. Well over 95 percent of their budget was spent on personnel and basic maintenance. Research programs were heavily oriented towards narrow military $\mathrm{R} \& \mathrm{D}$, with hardware developments prevalent. The organization did not provide for efficient incorporation of COTS technologies. Almost ten years after the fall of the Berlin Wall, research was still oriented towards requirements of Cold war armies and the Bulgarian defense industrial complex, relying on ever narrowing markets. 


\section{$R \& D$ Reengineering}

The Concept for consolidation of the R\&D institutes, approved by the Minister of Defense in June 1999, called for a national re-engineering effort, intrinsic part of the plans for comprehensive defense reform. During 1999, the Bulgarian defense R\&D establishment underwent major restructuring. One consolidated organization was created out of four R\&D institutes within the Ministry of Defense. Under the name "Institute for Advanced Defense Research" (IADR), it became part of the "G.S. Rakovsky” Defense College in Sofia.

IADR provides support to defense policy formulation and defense planning in developing weapon systems, organizational structures, C2, infrastructure, air defense, logistics, etc. IADR scientists participate in the formulation of requirements towards specific weapon systems and materiel and assessment of products and systems. Additionally, they provide for continuity through teaching at the "Rakovsky" College and education of doctoral students.

The budget for defense $R \& D$ is rapidly growing (see Table 1). According to the Ministerial Programming Guidance, constrained by the input of the Ministry of Finance, by the year 2005 the R\&D budget will reach 1.2-1.5 percent of the defense budget - a figure typical for Western NATO member countries of similar size and ambition levels. The trend for the R\&D budget is represented on figure 5 .

Currently, the MoD contracts outside defense research in the following areas:

- Command and control systems;

- Computer networks;

- Decision support systems;

- Simulation in staff training;

- Information assurance;

- Implementation of space-based remote sensing technologies;

- Remotely controlled robots for hazardous environments;

- "Intelligent" / remotely controlled mine fields;

- Optical and electro-optical surveillance systems;

- Radar modernization;

- Information processing in radar systems;

- Protection from laser guided munitions;

- Passive protection of armored vehicles;

- $\quad$ NBC protection;

- Electro-chemical batteries. 
In the beginning of 2001, the Ministry of Defense structured science and technology and R\&D in a way similar to the one used by the NATO Research and Technology Organization. It covers nine broad areas ${ }^{20}$ :

1. Systems research;

2. Sensors and sensor systems;

3. Communications and information systems technologies;

4. Modeling and simulation;

5. Transport technologies;

6. Armaments and ammunition;

7. Materiel, incl. armor, explosives, cloth, fuels, etc.;

8. NBC defense and ecology;

9. Social, psychological and medical research.

\section{Cooperation}

The Bulgarian Ministry of Defense, in coordination with the Bulgarian Academy of Sciences, universities and the defense industry, works to structure better the national defense $R \& D$ efforts and to expand the cooperation in $R \& D$ and technology development with other countries, primarily NATO and EU members or aspirants.

At the end of 1999, the Ministry of Defense signed a Framework agreement for cooperation with the Bulgarian Academy of Sciences. ${ }^{21}$ In the spring of 2001 similar agreement was signed with the University of National and World Economics. Agreements with other leading Bulgarian universities are under preparation.

Bulgaria regularly participates in the meetings of the NATO Research and Technology Board (RTB), open for partner countries. R\&D cooperation is established also on a bilateral basis. During the year 2000, a Dutch-Bulgarian Memorandum of Understanding regarding exchange of data and cooperation in defense research and technology was signed. ${ }^{22}$ The first joint project in the area of space based remote sensing was successfully accomplished in 2000. Several new joint projects are underway.

Bulgarian research institutes have established cooperation with US defense R\&D organizations, mainly through the Edison House in London. Several joint projects have been accomplished or are currently implemented. Most notable are the projects in the area light armor and naval mine warfare.

The international $\mathrm{R} \& \mathrm{D}$ cooperation has a driving role for reengineering Bulgarian defense research. It provides focus in conceptualizing, expanding the research area and addressing new requirements. Furthermore, it allows transfer of R\&D 
management practices and facilitates international cooperation activities of Bulgarian universities and research institutes.

Thus, the $\mathrm{R} \& \mathrm{D}$ reengineering contributes to increased compatibility between Bulgaria and NATO and member countries. It provides a foundation for increased international cooperation in the future, i.e., in the area of joint procurement.

\section{Defense modernization as driver for cooperation}

During the last decade the Bulgarian armed forces have been significantly decapitalized. No major platforms have been acquired in more than twelve years. However, national security requirements and the perspective for NATO and EU membership drive a defense reform allowing for extensive modernization. Combined with the rapidly increasing levels of training and $R \& D$ (see figure 5), modernization may have a catalyzing effect on economic development and international defense industrial cooperation.

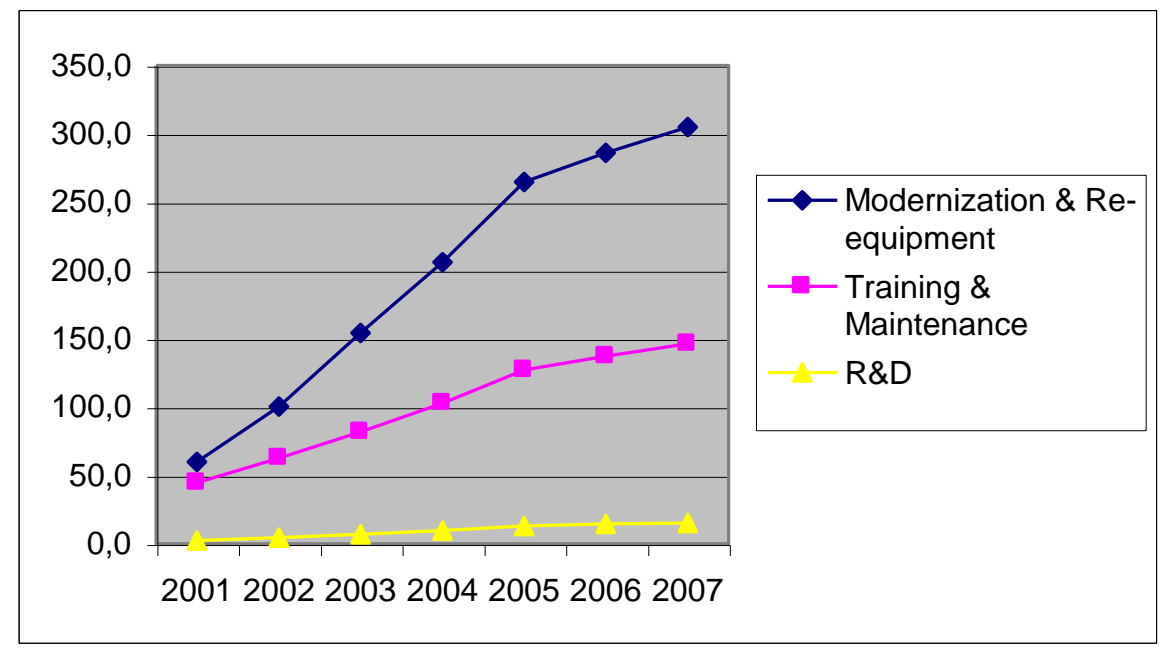

Figure 5. Economic potential of defense modernization (Resource allocations in million BG Levs).

Cooperation in the area of $\mathrm{R} \& \mathrm{D}$ is just one example how defense reform and modernization may contribute to economic development through technological advancement. The cooperation on a national level among the Ministry of Defense, the academic sector and the defense industry has the potential to maintain and find new niches of competitiveness on the global markets. 
This cooperation will be stronger if the coordination among various Bulgarian users is improved. Given the changes in the security environment after the end of the Cold war, and in particular the rising importance of risks and threats that do not fit traditional patterns of military threats, Bulgarian defense planers pay considerable attention to the integration of various security instruments. The 1998 Concept for National Security and the 1999 Military Doctrine envision and require such integration. ${ }^{23}$ Thus, the armed forces, the troops of the Ministry of Interior, in particular Border Police and the Gandarmerie type of units, the Civil Protection Agency and the security services need to provide complementary capabilities to undertake the full spectrum of missions and tasks in order to guarantee the national security of Bulgaria. These capabilities will be sustained in terms of organization, procedures (doctrine), training and technology, Respectively, modernization plans should account for interoperability with emphasis on all command and control functions, and when practical, commonality of weapon systems, equipment and infrastructure.

The MoD science and technology, $\mathrm{R} \& \mathrm{D}$, test and evaluation programs are tools for national integration, and at the same time - vehicle for integration of the Bulgarian scientific, $R \& D$ community in the respective communities of the Western democracies.

Furthermore, the availability of compatible acquisition processes would allow exploration of various frameworks for cooperation. One obvious framework is the cooperation in South Eastern Europe building on the successful security and defense cooperation. ${ }^{24}$ Another potential framework is among the former Warsaw Pact member countries, having similar equipment and dealing with similar heritage.

One potential start is in the area of defense technology demonstrations, using the traditional exhibition of defense industries HEMUS in Plovdiv, Bulgaria. The next exhibition is scheduled for the last week of May 2002. Several seminars are planned during the exhibition:

- Modernizing Forces to Meet the New Security Challenges;

- Second Regional C4 Conference: System Integration and Project Management;

- International Research Cooperation in Support of Force Modernization. ${ }^{25}$ These seminars will serve to discuss the plans for modernization of the Bulgarian armed forces, to elaborate the policy for their implementation, and to facilitate the building of strategic partnerships between users, defense industries and scientists, as well as among the countries in South-East Europe. 


\section{Conclusion}

A comprehensive defense reform is under way in the Republic of Bulgaria. It requires and creates conditions for modernization of the Bulgarian armed forces. The Ministry of Defense has laid the foundations for effective force modernization that is also in the broader interests of the society.

There is still room for improvement. One major challenge is the elaboration and the implementation of consistent procedures for defense acquisition. Another challenge is the education and training of decision makers in the area of acquisition - from the member of Defense Committee in Parliament overseeing defense modernization to the officer and the civil servant who bear responsibility for a specific modernization project. Finally, Bulgaria would benefit from participation in multinational agreements on procedures and organizations for joint procurement.

Without breaking the relations with its traditional partners, Bulgaria is reorienting the modernization programs towards cooperation with future allies and partners from NATO and the European Union. Using its traditional strengths, scientific and research potential, Bulgaria needs to build strategic industrial partnerships with its future allies.

Of paramount importance is the transparency of force modernization policy. Modernization plans should be transparent to Parliament, to society, to allies and neighbors. Bulgaria needs to show that the modernization of its forces is not aimed against a particular country, but is a tool for contribution to its own security, its future responsibilities as NATO ally, and the regional stability. A similar policy of all countries in South Eastern Europe will have a stabilizing effect in the region, while the cooperation in force modernization would allow for effective development of cooperative crisis management capabilities in the best interests of the region and the international community. 
Annex A

\section{Missions and Tasks of the Bulgarian Armed Forces}

M1: Peacetime functions (non-crisis situation). The Armed Forces execute tasks connected with the protection of the national integrity and sovereignty. They participate with personnel and equipment in multinational peace forces. The Armed Forces carry out activities related to the preparation of the central and local administration and the population for common action in times of crises of various nature. They participate in building dual-use infrastructure. The Armed Forces perform representative functions.

M2: Participation in the management of crises of non-armed nature. The Armed Forces participate in operations in the context of protecting the civilians and elimination of the consequences of natural disasters, industrial accidents and catastrophes. They take part in elimination of the consequences of dangerous pollution in Bulgaria and abroad. In conformity with national and international law the Armed Forces are ready to provide humanitarian assistance, to execute rescue operations on the territory and aquatory of the country and abroad whenever asked to assist the civilian authorities.

M3: Contribution to guaranteeing the internal security of the country. The Armed Forces contribute to safeguarding the national integrity, to securing the internal order through counteraction to any forces that aim at impairing the national integrity or alteration of the form of government by means of force. The Armed Forces support the civilian authorities, when requested, in operations against terrorism, organized crime, trafficking of people and drugs, illegal arms trade, smuggling technologies, strategic materials and products that may serve as a basis for construction, production or use of weapons of mass destruction.

M4: Multinational crisis response operations. The Armed Forces participate in conflict prevention, peace support operations (peace keeping, peace enforcement, peace building, etc.) and operations other than war as part of multinational contingents in accordance with the agreements and based on the mandate of an international organization.

M5: National defense. The Armed Forces defend the land, sea and air borders of the country. In times of evolving military-political crisis and a direct threat to the country, the Armed Forces may increase their forces for deterrence and defense and execute activities connected with the defense of troops, important sites and civilian population. In case of a spreading conflict within Bulgaria, under the provisions of article 17 of the Military Doctrine, the Armed Forces 
build-up the theatre-of-military-operations group of forces, carry out operational and, if needed, strategic deployment; they block the aggression through intensive combat activities and execute decisive counteractions in order to restore the national integrity.

M6: Collective defense. The Armed Forces and infrastructure are prepared to participate, in perspective, in collective defense according to article 5 of the Washington Treaty on the territory of the country as well as outside it.

The Armed Forces build and maintain capabilities for the execution of the following tasks:

\section{Peacetime Tasks}

T1. Strategic intelligence. Independently or in cooperation and interaction with other national bodies and through exchange of information with strategic partners, and future allies, the Armed Forces maintain a picture of the situation in regions of interest to the national security for the needs of the early warning and military-political decision support;

T2. Airspace management and air sovereignty;

T3. Aquatorial control and navigation support;

T4. Participation in the implementation of international treaties and initiatives related to the enhancement of confidence and cooperation in the military field;

T5. Participation with personnel and equipment in multinational peace forces;

T6. Ceremonial functions;

T7. Transportation of (VIP) statesmen;

T8. Participation in the preparation of the population, national economy and wartime reserves for protection in crises of different nature and preparation of the country for defense;

\section{Crises of non-armed nature}

T9. Protection of the population in natural disasters, industrial accidents and catastrophes;

T10. Humanitarian assistance in international humanitarian crises; 
T11. Support of the civilian authorities in counteracting non-military threats of (potentially) armed character: illegal traffic of people and weapons, drug traffic, organized crime and in maintenance of law and order;

Crisis response

T12. Participation in peace-support operations;

T13. Search and rescue;

T14. Personnel evacuation from crisis areas;

National Defense

T15. Information superiority (Military Doctrine, article 62);

T16. Conducting of defense operation in line with article 17 of the Military Doctrine;

T17. Territorial defense;

Collective Defense

T18. Participation (following NATO accession) in defense operations of the allied forces.

\section{Notes:}

1 Plamen Pantev, ed., Civil-Military Relations in South-East Europe: A Survey of the National Perspectives and of the Adaptation Process to the Partnership for Peace Standards (Vienna: Institut fuer Internationale Friedenssicherung, 2001). The full text is available at http://www.isn.ethz.ch/isis.

2 National Security Concept of the Republic of Bulgaria, State Gazette 46 (22 April 1998). Available full text in English at http://www.md.government.bg.

3 Military Doctrine of the Republic of Bulgaria, Approved by the XXXVIII National Assembly of the Republic of Bulgaria on April 8, 1999 (Sofia: Military Publishing House, 1999). Full text in English is available at http://www.md.government.bg.

4 Tagarev, T., "Transparent Defence Planning for Effective Democratic Control," in PFP Planning Symposium (Oberammergau, Germany: January 2001). Slides are available at http://www.isn.ethz.ch/pfpdc/e_index.htm.

5 Velizar Shalamanov, ed., Cornerstones of Bulgarian Security and Defence Policy (Sofia: Ministry of Defence, July 2001).

6 Shalamanov, Cornerstones.

7 The figures for "modernization" and "investment" differ. According to Bulgarian legislation, modernization, re-equipment and new defense infrastructure spending 
constitutes only part of the investment budget. The latter further includes overhaul of weapon systems, equipment and infrastructure, as well as building of barracks, housing, etc. The adoption of common NATO definitions is strongly recommended.

Gilles Andreani, Christoph Bertram and Charles Grant, Europe's Military Revolution (London: Centre for European Reform, March 2001).

Thomas S. Szayna, NATO Enlargement, 2000-2015: Determinants and Implications for Defense Planning and Shaping, RAND Report MR-1243-AF (RAND Corporation, 2001). Available at http://www.rand.org/publications/MR/MR1243/

Szayna, NATO Enlargement.

Review of Force Structures in Implementation of Partnership Goal G 0028, Preliminary Report for Consultations with NATO (Sofia: Ministry of Defense, 28 May 2001).

See for example The Acquisition Handbook: A Guide to Smart Procurement, Edition 3 (London: Ministry of Defence of the United Kingdom, June 2000); US Acquisition System, DoDD 5000 series; Defence Materiel Selection Process: The Outlines for Procurement of Materiel (The Hague: Directorate-General for Materiel, Ministry of Defence of The Kingdom of the Netherlands, 1999).

See the articles by Stoyan Balabanov, "Field Integrated Communication and Information System for Bulgarian Land Forces" in this volume, and by Stoyan Avramov, "ASOC and C4I Systems Integration" in volume 7, 2002.

Law on Public Tenders, State Gazette 56 (22 June 1999).

Instruction on Planning, Organization and Control of Logistic Support, Construction and Construction Services in the Ministry of Defense, Instruction \# 1 (7 February 2001). Available in Bulgarian at http://www.md.government.bg.

Bulgarian Defense Reform Study, Final Report (Washington, DC: The Office of the Assistant Secretary of Defense for International Security Affairs and U.S. EUCOM, July 1999).

Recommendations for the development of the Plan for Organizational Evolvement of the Ministry of Defense and the Armed Forces until the year 2004 (Sofia: Ministry of Defense of the Republic of Bulgaria, May 1999).

Command, Control, Communications and Computers Study for Bulgaria (Hanscom AFB: USAF ESC/MITRE, January 2000); Main Recommendations for the development of C4I Systems (Sofia: Ministry of Defense, May 2000).

Details are provided in the article by Velizar Shalamanov in this volume.

Tagarev, T., "Organization of Scientific Research and Development in the Interest of Defense," Military Journal 108, 1 (2001): 35-45.

The Bulgarian Academy of Sciences includes approximately 70 institutes and laboratories with over 8,000 personnel. Approximately 3,500 of these are scientists. In order to improve coordination of its defense and dual use research activities, in the spring of 2001 the leadership of the Academy created a Center for National Security and Defense Research <http://www.icsr.bas.bg/cnsr/>.

Memorandum of Understanding between the Ministry of Defence of the Republic of Bulgaria and the Minister of Defence of the Kingdom of the Netherlands regarding exchange of data and co-operation in defence research and technology, August 2000.

Confirmed through the list mission and tasks in the Defense Programming Guidance 2002-2207, given also in the Annex. 
24 See for example Gül Sosay, "Regional Security Challenges and Opportunities in the Balkans," in International Seminar on Regional Security Challenges and Opportunities in the Balkans: Towards Harmonized Perceptions and Cooperative Security Studies (Istanbul: Center for European Studies, April 2001). Available electronically at http://www.isn.ethz.ch/pfpdc/e_index.htm.

25 Current information about the seminar will be available at the Web site of the Center for National Security and Defense Research at the Bulgarian Academy of Sciences.

Since May 2001 Dr. TODOR TAGAREV is Director of the Armaments Policy Directorate of the Bulgarian Ministry of Defense and National Armaments Director. Prior to that, he was the first Director of the Defense Planning Directorate since its establishment in May 1999. In 1982 he graduated from the Bulgarian Air Force Academy with M.Sc. degree in Automatics (Aviation Weapon Systems and Missile Technology) and in 1989 received a Ph.D. degree in control and systems research from the 'Zhukovsky' Air Force Engineering Academy, Moscow, Russia. Dr. Tagarev is a 1994 Distinguished Graduate of the US Air Command and Staff College and 1994 Distinguished Young AFCEAn. He holds Associate Professorship and is a Senior Research Associate of the Institute for Security and International Studies, Sofia, Bulgaria. Dr. Tagarev is Managing Editor of 'Information \& Security. An International Journal' and member of the Editorial Board of 'Military Journal'. He has published extensively in the areas of defense planning, information aspects of security, computer studies, modeling and prediction of complex processes, including security processes and defense related issues. 